\title{
SHORT-LIVED INFECTION WITH ENTEROCOCCI OF MOUSE OVIDUCT FOLLOWING MATING
}

\author{
A. K. TARKOWSKI, MARIA SMORAWIŃSKA* AND \\ LUDMIEA JANOTA-BASSALIK* \\ Department of Embryology and *Department of Microbiology, Warsaw University, \\ Warsaw, Poland \\ (Received 9th Fanuary 1969)
}

\begin{abstract}
Summary. On the 1st day after mating, the oviducts of the mouse are infected with bacteria. Infection is eliminated within 24 to $36 \mathrm{hr}$, presumably by the leucocytes appearing at this time in the genital tract. Two groups of strains, one producing a greenish discolouration of the blood and the other $\beta$-haemolytic, were isolated from the oviducts and were identified as being most probably varieties of enterococci. In the bacterial flora of vaginae, non-haemolytic streptococci, closely related to those isolated from the oviducts, predominated.
\end{abstract}

\section{INTRODUCTION}

In mammals, copulation usually results in the introduction of bacteria into the lumen of the uterus, but such infection, apart from pathological cases, is relatively short-lived. In the mouse, uterine infection with enterococci was reported by Austin (1957), who also found that the microflora were particularly abundant from 14 to $24 \mathrm{hr}$ after ovulation. The duration of this infection and the mechanism of its elimination have not so far been elucidated, nor is it known whether the infection is confined to the uterus only, or whether the bacteria are able to pass the tubo-uterine junction and infect the oviduct.

In the unpublished experiments of one of us (A.K.T.) on the organ culture of mouse oviducts, infection was noted in oviducts which were explanted with aseptic precautions on the 1st day of pregnancy and transferred to a culturemedium not containing antibiotics (the 1st day on which a vaginal plug was found was taken as the 1st day of pregnancy). Infection was not observed in oviducts explanted on the 2nd or 3rd day, nor in those oviducts explanted on the 1st day which were subsequently cultured on a medium containing penicillin and streptomycin. Similar observations were reported by Cole (1965) and by Mintz (1965). These authors noted that when oviducal mouse eggs were cultured in a medium without antibiotics, only the cultures containing one-cell eggs were found to be contaminated. These fragmentary data formed the starting point of the present study.

\section{MATERIALS AND METHODS}

Mice of inbred strains, A, GBA-p, and CBA-T6T6 and at an average age of $2 \frac{1}{2}$ months, were used. The animals were killed by cervical dislocation. Dissection 
was carried out in a box previously sterilized with a Phillips TUV 30-watt lamp. The oviducts were excised above the tubo-uterine junction and transferred to glass hand-homogenizers to be homogenized in $0.15 \mathrm{ml}$ of saline solution. The number of bacteria in the homogenate was determined by spreading on an agar surface and counting the colonies that developed on subsequent incubation of the plates. The following dilutions made in saline were plated: $10^{0}, 10^{-1}, 10^{-2}, 10^{-3}$ for oviducts from the 1st and 3rd day of pregnancy, and $10^{\circ}$ for oviducts from the $2 \mathrm{nd}, 5 \mathrm{th}, 10 \mathrm{th}, 15$ th and 19th day of pregnancy and from unmated mice. Colonies were examined after 24 and $48 \mathrm{hr}$ incubation at $37^{\circ} \mathrm{C}$. The following media were used: nutrient broth, and nutrient agar with and without the addition of $5 \%$ sheep's blood.

The isolated strains were stored for 6 weeks on nutrient agar, and then on nutrient blood agar. Observations of the isolated strains were made on 'enriched media' after the method described by Pelczar, Bard, Burnet \& Conn (1957). The tests for growth in the presence of $10 \%$ sodium desoxycholate and in $2 \%$ or $6.5 \% \mathrm{NaCl}$ broth were carried out after the method of Kolmer (1952). The isolated strains were identified according to the criteria of Breed, Murray \& Smith (1957).

\section{RESULTS}

Forty-one mice, thirty-five of which had mated, were examined, ten animals on the lst day of pregnancy, seven on the 2nd, ten on the 3rd and two on each of the 5th, 10th, 15th and 19th days. On the 1st day of pregnancy, bacterial infection of the oviducts was found in seven out of ten females. Infection amounted to $10^{3}$ to $10^{5}$ 'colony forming units' per homogenate of both oviducts. The oviducts of twenty-four out of twenty-five mice at later stages of pregnancy were not infected. The only exception was one mouse on the 3rd day of pregnancy, in which the oviducts were infected to the extent of $10^{3}$ 'colony forming units'. The oviducts of the unmated mice were not infected.

The nine strains of bacteria isolated at random proved to be cocci occurring singly, in pairs or in short chains. In six of the strains, the diameter of cells was about $1 \mu$ and in the remaining three strains, $1 \cdot 1$ to $1.3 \mu$. Colonies grown for 18 to $24 \mathrm{hr}$ were round, smooth and measured 1 to $2 \mathrm{~mm}$ in diameter. All strains were Gram-positive, non-motile and non-sporulating; all grew at $24^{\circ}$ and $45^{\circ} \mathrm{C}$ in the presence of $2 \%$ and $6.5 \% \mathrm{NaCl}$ as well as in the presence of $0.1 \%$ methylene blue. Two groups of strains were differentiated, those producing a greenish discoloration of blood and those which were $\beta$-haemolytic. All of them belonged most probably to the enterococci.

Qualitative bacteriological examination of mouse vaginae revealed the presence of abundant, non-haemolytic microflora with a uniform type of colony. Morphological and physiological tests, to which two strains isolated at random were submitted, pointed to their identity with strains isolated from the oviducts and identified most probably as Streptococcus faecalis.

\section{DISCUSSION}

The results of the present study make it possible to conclude that (1) infection 
of the genital tract occurs regularly as the result of copulation, and (2) infection is not restricted to the uterus but affects the whole genital tract, including the oviducts.

The fact that vaginal strains are closely related to those found in the oviduct suggests that the bacterial flora normally living in the vagina are the probable source of infection, but contamination of the semen itself (cf. McDonald, Black, McNutt \& Casida, 1952) may also contribute to this infection.

Elimination of the oviducal infection 24 to $36 \mathrm{hr}$ after copulation coincides in time with the appearance of numerous leucocytes in the genital tract. Leucocytosis in the genital tract occurs regularly at the end of oestrus in both unmated and mated mice, but the infiltration of leucocytes into the lumen of the tract is more intense in those females which had mated (Austin, 1957). It is not quite clear what are the factors which stimulate this infiltration. According to Austin, it is the distention of the uterus, while Yanagimachi \& Chang (1963), who worked with the hamster, attributed the leucocytic infiltration to the presence in the uterus of the spermatozoa. On account of the results of studies by McDonald et al. (1952), Yanagimachi \& Chang do not exclude the possibility that the infiltration of leucocytes may also, to a certain extent, be caused by the bacteria introduced into the uterus during copulation.

Studies by Austin (1957), Menge, Tyler \& Casida (1962) and Yanagimachi \& Chang (1963) provide evidence that, in the mouse, rat, hamster and rabbit, leucocytes phagocytose spermatozoa and play an important rôle, though to a different degree in different species, in the elimination of spermatozoa from the lumen of the genital tract. It seems most likely that the bacteria introduced into the genital tract as the result of copulation are eliminated in a similar way. The evidence in favour of this view is provided by studies of Hawk (1958), Hawk, Turner \& Sykes (1960), Winter, Simon, McNutt \& Casida (1960) and Broome, Winter, McNutt \& Casida (1960) who found that the bactericidal properties of the rabbit uterus experimentally infected with Escherichia coli and Staphylococcus aureus are clearly connected with the occurrence of leucocytes and the intensity of their infiltration. In addition, Broome et al. (1960) observed the phagocytosis of bacteria (Staphylococcus aureus) by neutrophil leucocytes.

\section{REFERENCES}

Ausrin, C. R. (1957) Fate of spermatozoa in the uterus of the mouse and rat. F. Endocr. 14, 335.

Breed, R. S., MURRAy, E. G. \& SMith, N. R. (1957) Bergey's manual of determinative bacteriology. Williams \& Wilkins, Baltimore.

Broome, A. W., Winter, A. J., MaNutt, S. H. \& CAstda, L. E. (1960) Variations in uterine response to experimental infection due to the hormonal state of the ovaries. II. The mobilization of leukocytes and their importance in uterine bactericidal activity. Am. 7. vet. Res, 21, 675.

CoLe, R. J. (1965) In Discussion. Preimplantation stages of pregnancy. CIBA Fdn Symp., p. 402. Churchill, London.

Hawk, H. W. (1958) The influx of leukocytes and presence of bactericidal substances in inoculated uteri of estrous and pseudopregnant rabbits. F. Anim. Sci. 17, 416.

Hawk, H. W., Turner, G. D. \& SyKes, J. F. (1960) The bactericidal properties of uteri and uterine exudates of rabbits with reduced leukocytic activity. Am. F. vet. Res. 21, 649.

Kolmer, J. A. (1952) Approved laboratory technic. Lewis, London.

MaDonald, L. E., Black, W. G., MaNutt, S. H. \& Casida, L. E. (1952) The response of the rabbit uterus to instillation of semen at different phases of the estrous cycle. Am. F. vet. Res. 13, 419.

Menge, A. C., Tyler, W. J. \& Casida, L. E. (1962) Factors affecting the removal of spermatozoa from the rabbit uterus. $\mathcal{J}$. Reprod. Fert. 3, 396. 
Mintz, B. (1965) In Discussion. Preimplantation stages of pregnancy. CIBA Fdn Symp., p. 402. Churchill, London.

Pelczar, M. J., Bard, R. G., Burnet, G. W. \& Conn, H. J. (1957) Manual of microbiological methods. McGraw-Hill, New York.

Winter, A. J., Simon, J., MaNutt, S. H. \& Casida, L. E. (1960) The effect of an induced state of leukopenia on the uterine bactericidal activity in rabbits. Am. 7. vet. Res. 21, 664 .

Yanagmach, R. \& Chang, M. C. (1963) Infiltration of leucocytes into the uterine lumen of the golden hamster during the oestrous cycle and following mating. 7. Reprod. Fert. 5, 389. 